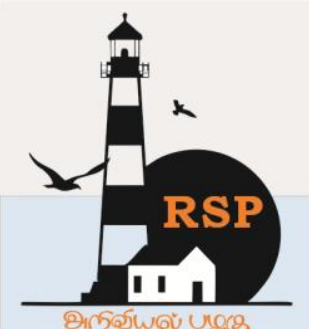

INTERNATIONAL RESEARCH JOURNAL ON ADVANCED SCIENCE HUB

RSP SCIENCE HUB

(The Hub of Research Ideas)

Available online at www.rspsciencehub.com

Special Issue of First International Conference on Management, Science and Technology (ICMST 2021)

\title{
A Study on Cost of Capital Analysis of Ports and Special Economic Zone Limited
}

R. R. Miruthubashini ${ }^{1}$, Dr. S. Vijayalakshmi ${ }^{2}$

${ }^{1}$ Department of B. Com (PA)., PSGR Krishnammal College for Women, Coimbatore, Tamilnadu, India.

${ }^{2}$ Professor, Department of B. Com (PA)., PSGR Krishnammal College for Women, Coimbatore, Tamilnadu, India.

18bpa058@psgrkcw.ac.in ${ }^{1}$

\begin{abstract}
Cost of capital analysis is a key concept of computing the cost that is incurred in various sources of business finance individually and as a whole. In other words, it is a method for analyzing the cost incurred in debt, equity, and other forms of investment in the company. The main objective of the project is to study the cost of Adani Ports and Special Economic Zone Limited and to suggest a proper capital budgeting decision to reduce the company's cost. In Adani Ports and Special Economic Zone Limited, the Cost of Capital Analysis aids to choose the best source of finance that suits the needs of the company based on the cost aspects.
\end{abstract}

Keywords: Cost of capital analysis, Business finance, Capital budgeting decision, Investment.

\section{Introduction}

The cost of capital is the return expected by the investors from various sources of investments. In other words, it is the cost of a firm's debt and shareholders' funds. In corporate world, they use many sources of funds such as Equity shares, Preference shares, Debentures, Term loan, Reserves and surplus, etc... in various permutations and combinations to finance their business, such corporate makes use of the weighted average cost of capital to determine the overall cost of investment in the business. From the view of investors, the result provided by the cost of capital analysis is the return that they expect. This also includes the risk involved in the business, as well. By analyzing this, the investors scrutinize the stability of the business to determine whether to invest in that company or not. [1-5].

\section{Review of Literature}

Surendra S Yadav and et al (2012)1, The purpose of this paper is to understand current practices in capital budgeting in Indian companies and provide guidelines for practitioners. They used questionnaire survey for administering Nonfinancial companies of the BSE 200 index. Secondary data were also collated from 2001 - 2011. The findings show that there still remain theory and practice gap in the usage of IRR over NPV.Roopali Batra and Satish Verma (2017)2, studies the Indian capital budgeting practices of 77 Indian companies listed in Bombay stock exchange. They discovered that weighted average cost of capital is most recommended. This study evaluated how various variables affects the capital budgeting decision of a company. Authors suggested that an upgradation in administrative procedures for capital budgeting by employing WACC for different projects or divisions and applying market values for weights. The other tools analyzed for capital budgeting are Discounted cash flow techniques such as net present value and internal rate of return, Payback period, CAPM model and risk adjusted discount rates.Babasaheb R. Jadhav (2017)3, The main principle of research was to explore the 
relationship between capital structure and cost of capital by examining the industries in Ahmednagar district, India. The statistical tools used in the hypothesis testing were Ratios and Proportions, Percentages and Weighted averages. One of the finding by calculating WACC was that the group of industries fell into 10-15\% weighted average cost of capital of the organization. He concluded by saying that the industries are aware of all techniques and change according to the changing circumstances. Dr. Amardeep (2013)4, in this journal he stated that the firm's cost of capital is important from the point of view of both capitals budgeting as well as capital structure planning decisions. He analyzed the components of capital of ABC Firm and explained clearly about each component. He concluded with the interesting point that, the Economic Value Added by the firm was negative during some of the years under study such as 2009-10, 2010-11 and 2011-12. In spite of this, the Firm has been paying dividend on its Equity Capital throughout all the years under study. Akarsh Singhal (2014)5, investigated the impact of corporate governance on firm performance and valuation. The tools used for analyzing cost of capital and performance of firm are weighted average cost of capital, cost of equity, Tobin Q return on capital employed, return on equity, sales growth and cost of debt. [610].The tools used to measure corporate governance are Board size, Board independence, CEO duality and ownership pattern in the company. The sample contains 30 SENSEX companies listed in Bombay Stock Exchange (BSE) for 10 years from FY 2003-04 to FY 201213. The main objective is to recognize the correlation between corporate governance variables and cost of capital of the company. Author concludes that competitive and legal infrastructure of the corporate has an important role improving company's performance thus enabling it to attract foreign capital which positively impacts cost of capital. He also suggests investors to invest in companies with better governance and portfolio. E. Chuke Nwude (2016)6, discusses the importance of correct and flawless calculation of cost of capital. He details formulas and ways to calculate cost for each source of funds. This project provides detailed understanding into various types of cost of capital thus acting as a guide about cost of capital to various beneficiaries. In summary, cost of capital is the rate the firm must earn for the investors to earn their required rate of return. From lender's point of view high cost of capital is better as it provides him with high returns. Whereas, from fund user's point of low cost of capital is ideal. Thus, author suggests that rate of cost of capital is required rate of return for company's all sources of funds. The tools analysed are cost of equity, cost of debt, cost of preference and cost of term loans. Mamatha. Ellanti (2016)7, used EVA method for evaluating the performance of 3 major Indian pharmaceutical companies namely Sun pharma, Cadilla healthcare and Ajantha pharma for 3 years from 2012 to 2015. EVA is financial device or tool to measure financials performance of a company by operating cash profit after adjusting tax from cost of capital. Author discussed in detail about formulas and calculation of weighted average cost of capital along with cost of each source of funds. She suggested that a company should choose sources of funds in such a way that cost of capital is at its minimum. She identified that most companies have enough profit yet their cost of capital is high which leads to negative EVA. Asha Sharma (2012)8, did cost of capital and profitability analysis of telecommunication industry. The objective of the author is to analyze the relationship between cost of capital and a company's profitability. Impact of cost of capital on profitability was discovered. The author discovered that the higher cost of capital adversely affects the profitability position of the companies. The author suggests that finance is an important aspect for any business thus proper sources of finance is to be used to ensure that cost of capital is under proper control. Author makes use of calculation and formulas of cost of capital of various as tools for analysis.Showkat Busru Ahmad Busru and et al (2019)9, The main objective of the study is to examine the effect of corporate governance mechanism on cost of capital in listed Indian firms and to determine vital areas in corporate governance which directly or indirectly contribute towards reducing capital cost of sample Indian listed firms. The sample includes 270 NSE listed Indian firms for period of nine years ranging from $2007-08$ to $2015-16$. The tool used is OLS multiple regression model. This study 
reveals that that board characteristics failed to affect cost of capital especially cost of debt. The authors' also advocate the effectiveness of corporate governance board structure, activities and disclosures are supporting the argument that potential investors in equity and debtholders get greater assurance and confidence on the company. Vinod K. Bhatnagar and et al (2015)10, This paper aims to evaluate the optimum capital structure, cost of capital and to analyze the impact of capital structure and cost of capital on shareholders' wealth maximization by studying 12 highest net worth companies listed on BSE stock exchange. Tools used for the analysis are regression analysis and use of arithmetical formula for calculating capital structure, shareholder's wealth and cost of capital. Result of the study shows that there is linearity between cost of capital and shareholder's wealth maximization while there is no relationship or linearity between shareholders' wealth maximization and capital structure. They suggest that in making decisions about maximizing shareholders' wealth, management must consider the long-run impact on the firm and must consider all those factors which are responsible of shareholders' wealth maximization.[11-16].

\section{Scope of the Study}

Cost of Capital is necessary to calculate the opportunity cost for various investments tied up with the Company. Once the costs are evaluated, the management can make better decisions to maximize the profits are using a satisfactory combination of various sources of funds. This helps both the management and the investors of the company for the effective allocation of their funds.

\section{Statement of the Problem}

Adani Ports and Special Economic Zone Limited faced a fall in its net profit in the 4th quarter (march 2020), due to a large foreign exchange loss on FY 2019-2020. We have found that the net income of the company is facing downward trend during the present financial year also. Hence, our study upon the cost of capital of Adani Ports and Special Economic Zone Limited will analyze the cost and recommend increase in the net income by reducing the cost of capital.

\section{Objectives of the Study}

To evaluate the cost of various sources of finance of ports and Special Economic Zone Limited.

\section{Limitations of the Study}

$>$ The Market Price of the company shares is collected from other sources which may differ from the actual in financial.

$>$ The annual reports for the 5 years are taken from sources other than the company's websites.

$>$ Our suggestions and our analysis on cost are related only to the specific period.

\section{Data Sources and Methodology}

The data for conducting the study is collected from secondary sources. The secondary data is collected from the annual reports of the company from its website, and othersources mentioned in bibliography. The study covers the period of five financial years from 2015-2020. Tools used in the study are cost of equity, cost of preference, cost of debentures, cost of term loan and weighted average cost of capital. Trend analysis is used as a technique to study and compare the cost for the above study period.

\section{Profile of Adani Ports and Special Economic} Zone Limited

Adani Group, is an Indian multinational conglomerate company having its headquarters at Ahmedabad, Gujarat, India. It was founded by Gautam Adani in the year 1988 as a commodity trading business, with the heading company as Adani Enterprises Limited which was previously known as Adani Exports Limited. Gautam Adani is the chairman of Adani group. Recently the group has expanded its business into areas such fields such as agribusiness, energy, real estate, logistics, consumer finance, public transport infrastructure, aerospace and defense.The combined revenue of Adani group is around $\$ 15$ billion with operations at 70 locations across 50 countries. It possesses employee strength of more than 17,000 as on 2020. Adani Ports and Special Economic Zone Limited (APSEZ) represents a large network of ports with India's largest SEZ at Mundra, Gujarat. It has changed its name from Mundra Port and Special Economic Zone Limited to its present name on 6th January, 2012.APSEZ Port Business is integral to its logistics business and is India's largest private port operator with presence across ten locations in six maritime states Gujarat, Goa, Kerala, Andhra Pradesh, Tamil Nadu and Odisha. These ten ports altogether contain 45 berths and 14 terminals. APSEZ 
www.rspsciencehub.com

operates three logistics parks located at Patli in Haryana, Kila-Raipur in Punjab and Kishangarh in Rajasthan through its subsidiary Adani Logistics Limited.

9.1 Calculations of Cost of Capital:

9.1.1 Cost of Equity

$$
K_{e}=\frac{D}{P_{0}}
$$

Table.1.Cost of Equity

\begin{tabular}{|c|c|c|c|}
\hline YEAR & $\begin{array}{c}\text { Dividend } \\
\text { Per Share }\end{array}$ & $\begin{array}{c}\text { Net } \\
\text { Proceeds } \\
\text { from } \\
\text { Share (Po) } \\
\text { (in Rs) }\end{array}$ & $\begin{array}{c}\text { Cost of } \\
\text { Equity } \\
\text { (Ke) (in } \\
\text { \%) }\end{array}$ \\
\hline $2015-2016$ & 2.20 & 248 & 0.89 \\
\hline $2016-2017$ & 0 & 344 & 0 \\
\hline $2017-2018$ & 1.30 & 368 & 0.35 \\
\hline $2018-2019$ & 2.00 & 383 & 0.52 \\
\hline $2019-2020$ & 3.40 & 261 & 1.30 \\
\hline
\end{tabular}

(Source: compiled from annual reports of the company 2015-2016 to 2019-2020)

\subsubsection{Cost of Preference share}

$$
K_{p}=\frac{P D+\frac{(R V-N P)}{n}}{\frac{(R V-N P)}{2}}
$$

\begin{tabular}{|c|c|c|c|c|}
\hline YEAR & $\begin{array}{c}\text { Redem } \\
\text { ption } \\
\text { price } \\
\text { per } \\
\text { share } \\
\\
(\mathbf{R V}) \\
(\text { in } R s)\end{array}$ & $\begin{array}{c}\text { Net } \\
\text { proceed } \\
\text { s from } \\
\text { share } \\
\text { (NP) (in } \\
\text { Rs) }\end{array}$ & $\begin{array}{l}\text { No of } \\
\text { years } \\
\text { of } \\
\text { redem } \\
\text { ption } \\
\text { (n) }\end{array}$ & $\begin{array}{c}\text { Cost of } \\
\text { Prefere } \\
\text { nce }\end{array}$ \\
\hline $2015-2016$ & 990 & 10 & 10 & 19.6 \\
\hline 2016-2017 & 990 & 10 & 10 & 19.6 \\
\hline $2017-2018$ & 990 & 10 & 10 & 19.6 \\
\hline $2018-2019$ & 990 & 10 & 10 & 19.6 \\
\hline $2019-2020$ & 990 & 10 & 10 & 19.6 \\
\hline
\end{tabular}

Table.2.Cost of Preference share

(Source: compiled from annual reports of the company 2015-2016 to 2019-2020)

Note: Preference dividend is nil for the study period (2015-20)

9.1.3 Cost of Retained Earnings

$$
K_{s}=K_{e}-t_{p}
$$

\begin{tabular}{|c|c|c|c|}
\hline YEAR & $\begin{array}{c}\text { Cost of } \\
\text { Equity } \\
\left(\begin{array}{c}\text { Ke) (in } \\
\%)\end{array}\right.\end{array}$ & $\begin{array}{l}\text { Personal } \\
\text { tax rate } \\
\text { (tp) (in \%) }\end{array}$ & $\begin{array}{c}\text { Cost of } \\
\text { Retained } \\
\text { Earnings } \\
(\mathrm{Kr})(\text { in \%) }\end{array}$ \\
\hline $2015-2016$ & 0.89 & 45 & 0.49 \\
\hline 2016-2017 & 0 & 45 & 0 \\
\hline 2017-2018 & 0.35 & 45 & 0.19 \\
\hline 2018-2019 & 0.52 & 45 & 0.29 \\
\hline 2019-2020 & 1.30 & 45 & 0.72 \\
\hline
\end{tabular}

Volume 03 Issue 06S June 2021

Table.3. Cost of Retained Earnings

(Source: compiled from annual reports of the company 2015-2016 to 2019-2020)

9.1.4 Cost of Debentures:

$$
K_{d}=\frac{I(1-t)+\frac{(R V-N P)}{n}}{\frac{(R V-N P)}{2}}
$$

Table.4. Cost of Debentures

\begin{tabular}{|c|c|c|}
\hline YEAR & $\begin{array}{c}\text { Interest Per } \\
\text { Debenture } \\
\text { (I)(in Rs) }\end{array}$ & $\begin{array}{c}\text { Cost of } \\
\text { Debentures } \\
\text { (Kd)(in \%) }\end{array}$ \\
\hline $2015-2016$ & 90,500 & 6.34 \\
\hline $2016-2017$ & 90,500 & 6.34 \\
\hline $2017-2018$ & 90,500 & 6.34 \\
\hline $2018-2019$ & 90,500 & 6.34 \\
\hline $2019-2020$ & 0 & 0 \\
\hline
\end{tabular}

(Source: compiled from annual reports of the company 2015-2016 to 2019-2020)

Note: Redemption value(RV) and Net proceeds(NP) are same for the study period (201520) which is equal to Rs. $10,00,000$ and Life of debentures and corporate tax rate is 5 and $30 \%$ respectively for the study period.

9.1.5 Cost of Term loans:

$$
K_{t}=\frac{I(1-t)}{\text { Total Term loan amount }}
$$

Table.5. Cost of Term loans

\begin{tabular}{|c|c|c|c|}
\hline YEAR & $\begin{array}{c}\text { Term } \\
\text { loan(in Rs) }\end{array}$ & Interest & $\begin{array}{c}\text { Cost of } \\
\text { Term } \\
\text { Loans } \\
\text { (int)(in } \\
\text { \%) }\end{array}$ \\
\hline $2015-2016$ & 0 & $82,48,00,000$ & 0 \\
\hline $2016-2017$ & 0 & 0 & 0 \\
\hline $2017-2018$ & $4,86,00,000$ & $17,00,000$ & 2.45 \\
\hline $2018-2019$ & $5,94,00,000$ & $21,00,000$ & 2.45 \\
\hline $2019-2020$ & $\begin{array}{c}1489,97,00,0 \\
00\end{array}$ & $38,47,00,000$ & 1.81 \\
\hline
\end{tabular}


www.rspsciencehub.com

(Source: compiled from annual reports of the company 2015-2016 to 2019-2020)

Note: Corporate tax rate is $30 \%$ respectively for the study period.

\subsubsection{Weighted Average Cost of Capital}

Table.6. WACC 2015-16

\begin{tabular}{|c|c|c|c|c|}
\hline Name & $\begin{array}{c}\text { Amount } \\
\text { (Rs in } \\
\text { Crore) }\end{array}$ & Fraction & $\begin{array}{c}\text { Cost } \\
(\%)\end{array}$ & $\begin{array}{c}\text { Net } \\
\text { cost } \\
(\%)\end{array}$ \\
\hline Equity & 414.19 & 0.3145 & 0.89 & 0.28 \\
\hline Preference & 2.81 & 0.0021 & 19.6 & 0.04 \\
\hline Debenture & 900.00 & 0.6834 & 6.34 & 4.33 \\
\hline Term loan & 0 & 0 & 0 & 0 \\
\hline WACC & & & & 4.65 \\
\hline
\end{tabular}

(Source: compiled from annual reports of the company 2015-2016 to 2019-2020)

The following years (2016-20) are calculated same as the above.

\subsection{Trend Analysis}

Trend analysis is the extensive practice of collecting information and trying to spot a pattern. It is used to estimate uncertain events in past. In simple words, it is comparison of past and present to get an array.

\section{Formula for Trend Analysis}

$$
\begin{aligned}
& \text { Trend } \%=(\text { Current year's figure } \\
& \quad \div \text { Base year's figure }) \times 100
\end{aligned}
$$

\subsubsection{Cost of equity $\left(K_{e}\right)$}

Table.7.Trend analysis of Cost of equity

\begin{tabular}{|c|c|c|}
\hline \multirow{2}{*}{ Year } & \multicolumn{2}{|c|}{ Cost of equity (Ke) (in \%) } \\
\cline { 2 - 3 } & $\begin{array}{c}\text { Absolute } \\
\text { percentage }\end{array}$ & $\begin{array}{c}\text { Trend } \\
\text { percentage }\end{array}$ \\
\hline $2015-2016$ & 0.89 & 100 \\
\hline $2016-2017$ & 0 & 0 \\
\hline $2017-2018$ & 0.35 & 39 \\
\hline $2018-2019$ & 0.52 & 58 \\
\hline $2019-2020$ & 1.3 & 146 \\
\hline
\end{tabular}

(Source - The information is taken from secondary source)

The table 7 shows the trend analysis for cost of equity. Here 2015-2016 is taken as the base year. In the year 2016-2017, the trend is zero since there
Volume 03 Issue 06S June 2021

is $0 \% \mathrm{~K}_{\mathrm{e}}$. In 2017-2018, the change in cost of equity has decreased to $39 \%$ and in 2018-2019, the change in cost of equity has decreased to $58 \%$ compared with the base year. Then in 2019-2020, the change in $\mathrm{K}_{\mathrm{e}}$ increased by $46 \%$ compared with 2019-2020. The cost of equity was in fluctuation during the study period.

\subsubsection{Cost of Reserves}

Table.8. Trend analysis of Cost of reserves

\begin{tabular}{|c|c|c|}
\hline \multirow{2}{*}{ Year } & \multicolumn{2}{|c|}{ Cost of Reserves (in \%) } \\
\cline { 2 - 3 } & $\begin{array}{c}\text { Absolute } \\
\text { percentage }\end{array}$ & $\begin{array}{c}\text { Trend } \\
\text { percentage }\end{array}$ \\
\hline $2015-2016$ & 0.49 & 100 \\
\hline $2016-2017$ & 0 & 0 \\
\hline $2017-2018$ & 0.19 & 39 \\
\hline $2018-2019$ & 0.29 & 59 \\
\hline $2019-2020$ & 0.72 & 146 \\
\hline
\end{tabular}

(Source - The information is taken from secondary source)

The table 8 shows the trend analysis for cost of reserves. Here, 2015-2016 is taken as the base year. In the year 2016-2017, the trend is zero since there is $0 \% \mathrm{~K}_{\mathrm{s}}$. Then from the year 2017-2018 there is an increasing trend showing the increase in cost of reserves. The trend is highest in the year 2019-20, where cost is 0.72 .

\subsubsection{Cost of Preference}

Table.9. Trend analysis of Cost of preference

\begin{tabular}{|c|c|c|}
\hline \multirow{2}{*}{ Year } & \multicolumn{2}{|c|}{ Cost of Preference (in \%) } \\
\cline { 2 - 3 } & $\begin{array}{c}\text { Absolute } \\
\text { percentage }\end{array}$ & $\begin{array}{c}\text { Trend } \\
\text { percentage }\end{array}$ \\
\hline $2015-2016$ & 19.6 & 100 \\
\hline $2016-2017$ & 19.6 & 100 \\
\hline $2017-2018$ & 19.6 & 100 \\
\hline $2018-2019$ & 19.6 & 100 \\
\hline $2019-2020$ & 19.6 & 100 \\
\hline
\end{tabular}

(Source - The information is taken from secondary source)

The table 9 shows the trend analysis for cost of reserves. Here, 2015-2016 is taken as the base year. The trend from 2015-2016 to 2019-2020 is constant.

\subsubsection{Cost of Debentures}

The table 10. shows the trend analysis for cost of debentures. Here 2015-2016 is taken as the base year. There is a constant trend from 2015-2016 to 
2018-2019 indicating the constant $\mathrm{K}_{\mathrm{d}}$. In the year 2019-2020, the trend is zero since $K_{d}$ is zero.

Table.10. Trend analysis of Cost of Debentures

\begin{tabular}{|c|c|c|}
\hline \multirow{2}{*}{ Year } & \multicolumn{2}{|c|}{$\begin{array}{c}\text { Cost of Debentures (Kd) (in } \\
\text { \%) }\end{array}$} \\
\cline { 2 - 3 } & $\begin{array}{c}\text { Absolute } \\
\text { percentage }\end{array}$ & $\begin{array}{c}\text { Trend } \\
\text { percentage }\end{array}$ \\
\hline $2015-2016$ & 6.34 & 100 \\
\hline $2016-2017$ & 6.34 & 100 \\
\hline $2017-2018$ & 6.34 & 100 \\
\hline $2018-2019$ & 6.34 & 100 \\
\hline $2019-2020$ & 0 & 0 \\
\hline
\end{tabular}

(Source - The information is taken from secondary source)

\subsubsection{Cost of Term loan}

Table.11. Trend analysis of Cost of Term Loans

\begin{tabular}{|c|c|c|}
\hline \multirow{2}{*}{ Year } & \multicolumn{2}{|c|}{ Cost of Term loan (Kt) (in \%) } \\
\cline { 2 - 3 } & $\begin{array}{c}\text { Absolute } \\
\text { percentage }\end{array}$ & $\begin{array}{c}\text { Trend } \\
\text { percentage }\end{array}$ \\
\hline $2015-2016$ & 0 & 0 \\
\hline $2016-2017$ & 0 & 0 \\
\hline $2017-2018$ & 2.45 & 135 \\
\hline $2018-2019$ & 2.45 & 135 \\
\hline $2019-2020$ & 1.81 & 100 \\
\hline
\end{tabular}

(Source - The information is taken from secondary source)

The table shows the trend analysis for cost of Term Loans. Here 2019-2020 is taken as the base year. In 2017-2018, the trend is highest with the value 135 and the cost of $2.45 \%$. The Cost of Term Loan was in fluctuating trend.

\subsubsection{Weighted Average Cost of Capital}

Table.12. Trend analysis of Cost of Capital

\begin{tabular}{|c|c|c|}
\hline \multirow{2}{*}{ Year } & \multicolumn{2}{|c|}{ WACC (Ko) (in \%) } \\
\cline { 2 - 3 } & $\begin{array}{c}\text { Absolute } \\
\text { percentage }\end{array}$ & $\begin{array}{c}\text { Trend } \\
\text { percentage }\end{array}$ \\
\hline $2015-2016$ & 4.65 & 100 \\
\hline $2016-2017$ & 4.37 & 94 \\
\hline $2017-2018$ & 4.48 & 96 \\
\hline $2018-2019$ & 2.16 & 46 \\
\hline $2019-2020$ & 1.73 & 37 \\
\hline
\end{tabular}

(Source - The information is taken from secondary source)

The table shows the trend analysis for Cost of Capital of the Company by calculating the weights of each cost of funds associated with the business as investments. Here 2015-16 is taken as the base year. The WACC was in decreasing trend. It has attained its lowest percentage in 2019-20 with the overall cost of 1.73 .

\section{Findings}

From calculating cost of each source of fund for 5 years from financial year 2015-16 to 2019-20 for APSEZ it is evident that cost of preference shares is highest of all for all the years of observation. The next costly source is debentures but since all the debentures are redeemed in FY 2019-20 there is no cost of debenture in that year.The next source with high cost after debentures is the term loan. Cost of term loan present only in the financial years from $2017-18$ to $2019-20$ and the same is decreasing in the FY 2019-20 which is a good indicator since the company is majorly dependent on borrowing as a source of finance.Cost of equity is calculated using dividend price approach. Thus, it evident that the dividend distributed by the company over the study period is fluctuating with highest dividend declared in the year 2019-20.The source with least cost is retained earnings. Retained earnings is the net income that is accumulated and retained by the company after distributing dividend in order to be re-invested back into the business.

\section{Conclusion}

One of the best ways to reduce WACC is to reduce cost of equity. Cost of equity is the risk associated with future income generation, thus reducing the company's risk will reduce the cost. Risk can be reduced by increasing customer base, better corporate governance and internal control, employment of enough and highly qualified and competent workforce, taking new projects after proper planning and risk analysis and proper usage of funds in running the business. The company should not follow no or very low debt policy. It is better to have a capital structure that has more debt. Because interest paid on debt is taxdeductible and thus it reduces tax obligations. So, the after-tax cost of debt is lower than cost of equity. But there is a need to ensure proper regulation of debt because depending more on higher debt to reduce cost of capital will not give desired results in long run and there is chance that the company may get into debt trap.It is concluded from the trend analysis of the weighted average cost of capital that there is high chance for the same to reduce in the future. 


\section{Reference \\ Journals}

[1].Surendra S. Yadav, Shveta Singh, P.K. Jain (2012), "Capital budgeting decisions: evidence from India", Journal of Advances in Management Research, volume. 9, issue. 1, pg. 96-112.

[2].https://doi.org/10.1108/09727981211225671

[3].Roopali Batra, Satish Verma, 2017, "Capital budgeting practices in Indian companies", IIMB Management Review (2017), ISSN: 0970-3896, Volume 29, Issue 1, March 2017, Pages:29-44

https://www.researchgate.net/publication/3159 44985_Capital_Budgeting_Practices_in_Indian _Companies

[4]. Babasaheb R. Jadhav (2017), "The study of relationship between capital structure and cost of capital with respect to Industries from Ahmednagar District", International Journal of Management, IT \& Engineering, ISSN: 22490558, volume 7, issue 9, pg. 332-347.

[5].Dr. Amardeep (2013), "Impact of Cost of Capital in Decision-Making", Indian Journal of Applied Research", ISSN - 2249-555X, volume 3, issue 8, pg. 100-102.

[6]. Akarsh Singhal, 2014 "Corporate Governance, Cost of Capital and Value Creation: Evidence from Indian Firms", IOSR Journal of Economics and Finance (IOSR-JEF), e-ISSN: 2321-5933, p-ISSN: 2321-5925. Volume 4, Issue 6. (Jul-Aug. 2014).

[7].E. Chuke Nwude, 2016, "A review on the calculation of cost of capital", International Journal of Advanced and Applied Sciences, EISSN: 2313-3724, Print ISSN:2313-626X, Volume 3, Issue 8 (August 2016), Pages: 108-119.

[8].Mamatha. Ellanti, 2016, "SELECTED INDIAN PHARMACEUTICAL COMPANIES PERFORMANCE THROUGH EVA, A STUDY", International Journal of Science technology and Management, Volume No- 5, Issue no- 05, July 2016, ISSN- 23941537.

[9].Asha Sharma, 2012. "Cost of Capital and Profitability Analysis (A Case Study of Telecommunication Industry)", Journal of Commerce and Accounting Research, ISSN Number: 2277-2146, Volume 1 Issue 4.
[10].Showkat Busru Ahmad Busru, G. Shanmugasundaram, Aamir Rashid Bhat, 2019. "Corporate Governance and Its Impact on Cost of Capital: Empirical Insights from Indian Listed Firms", International Journal of Financial Management, ISSN Number: 22295682 Volume 9 Issue 1.

[11].Vinod K. Bhatnagar [Ph.D.], Manju Kumari and Nikku Sharma, 2015. "Impact of Capital Structure \& Cost of Capital on Shareholders' Wealth Maximization- A Study of BSE Listed Companies in India", Chanakya International Journal of Business Research, ISSN (Online):2395-2830, Volume 1(1), 28-36, March 2015.

\section{Books and Website}

[12].Managerial Accounting books.

[13].Intermediate course ICAI study material for Financial Management- Module 1

[14].https://www.moneycontrol.com

[15].https://www.adani.com/

[16].https://www.adaniports.com/ 